\section{Kidney Blood Pressure Research}

\title{
Tempol Protects Against Acute Renal Injury by Regulating PI3K/Akt/mTOR and GSK3 $\beta$ Signaling Cascades and Afferent Arteriolar Activity
}

\author{
Gensheng Zhang ${ }^{\mathrm{a}} \quad$ Qin Wang $^{\mathrm{a}} \quad$ Wenwen Wang ${ }^{\mathrm{b}} \quad$ Minghua Yu $^{\mathrm{b}}$ Suping Zhang ${ }^{\mathrm{a}}$ \\ Nan Xu ${ }^{a}$ Suhan Zhou ${ }^{a}$ Xiaoyun Cao ${ }^{a}$ Xiaodong Fu ${ }^{c}$ Zufu Ma ${ }^{d}$ Ruisheng Liue \\ Jianhua Mao ${ }^{\mathrm{a}}$ En Yin Laia
}

a'Department of Physiology, and the Children's Hospital, Zhejiang University School of Medicine, Hangzhou, 'Department of Pathology, Women's Hospital, Zhejiang University School of Medicine, Hangzhou, 'Department of Physiology, School of Basic Medical Sciences, Guangzhou Medical University, Guangzhou, 'Department of Nephrology, Tongji Hospital of Tongji Medical College, Huazhong University of Science and Technology, Wuhan, China, eDepartment of Molecular Pharmacology \& Physiology, University of South Florida College of Medicine, Tampa, Florida, USA

\section{Key Words}

Acute kidney injury • Ischemia/reperfusion • Tempol • Afferent arteriole

\begin{abstract}
Background/Aims: Free radical scavenger tempol is a protective antioxidant against ischemic injury. Tubular epithelial apoptosis is one of the main changes in the renal ischemia/ reperfusion (I/R) injury. Meanwhile some proteins related with apoptosis and inflammation are also involved in renal I/R injury. We tested the hypothesis that tempol protects against renal I/R injury by activating protein kinase $\mathrm{B} /$ mammalian target of rapamycin (PKB, Akt/mTOR) and glycogen synthase kinase $3 \beta$ (GSK3 $\beta$ ) pathways as well as the coordinating apoptosis and inflammation related proteins. Methods: The right renal pedicle of $\mathrm{C} 57 \mathrm{BI} / 6$ mouse was clamped for 30 minutes and the left kidney was removed in the study. The renal injury was assessed with serum parameters by an automatic chemistry analyzer. Renal expressions of $\mathrm{Akt} / \mathrm{mTOR}$ and GSK3 $\beta$ pathways were measured by western blot in I/R mice treated with saline or tempol $(50 \mathrm{mg} / \mathrm{kg})$ and compared with sham-operated mice. Results: The levels of blood urea nitrogen (BUN), creatinine and superoxide anion $\left(\mathrm{O}_{2}^{-}\right)$increased, and superoxide dismutase (SOD) and catalase (CAT) decreased significantly after renal I/R injury. However, tempol treatment prevented the changes. Besides, I/R injury reduced renal expression of $\mathrm{p}-\mathrm{Akt}$, p-GSK3 $\beta, p-m T O R, B c l 2$ and increased NF-KB, p-JNK and p53 in kidney, tempol significantly
\end{abstract}

G. Zhang, Q. Wang and W. Wang contributed equally to this work.

\begin{tabular}{ll}
\hline En Yin Lai, MD, PhD & Department of Physiology, Zhejiang University School of Medicine, \\
& Yuhangtang Road 866, Hangzhou 310058 (China) \\
E-Mail laienyin@zju.edu.cn
\end{tabular}




\section{Kidney Blood Pressure Research}

normalized these changes. In addition, renal $I / R$ injury reduced the response of afferent arteriole to Angiotensin II (Ang II), while tempol treatment improved the activity of afferent arteriole. Conclusion: Tempol attenuates renal I/R injury. The protective mechanisms seem to relate with activation of PI3K/Akt/mTOR and GSK3 $\beta$ pathways, inhibition of cellular damage markers and inflammation factors, as well as improvement of afferent arteriolar activity.

\section{Introduction}

Acute kidney injury (AKI) is a common and severe clinical disease. AKI occurs in approximately $5 \%$ of hospitalized patients and the overall mortality of AKI is estimated to range between $45-70 \%[1-3]$. AKI is responsible for approximately 2 million deaths annually worldwide $[2,4,5]$. Renal ischemia/reperfusion (I/R) injury is one of the major causes of AKI in clinics which could be happen in patients with kidney transplantation, crossclamping surgery, embolism in renal arteries and shock [6-8]. Although AKI has been studied extensively, the molecular mechanisms involved in renal injury are not fully addressed. Intracellular reactive oxygen species (ROS), pro-inflammatory cytokines and pro-apoptotic elements have been demonstrated to play an essential role in the development of AKI $[9,10]$.

The phosphoinositide 3-kinase/protein kinase B (PI3K/ PKB, Akt) pathway has been shown to play a critical role in regulating mitogenic signaling, apoptosis, cell proliferation and survival in different systems $[11,12]$. PI3K/Akt pathway mediates cell survival in renal cells [13], in which mammalian target of rapamycin (mTOR) and glycogen synthase kinase $3 \beta($ GSK-3 $\beta$ ) have been reported to play key role in Akt-mediated cell survival. The mTOR is an ubiquitously expressed intracellular serine/threonine protein kinase that plays a crucial role in regulating cell proliferation and organ growth by affecting many cellular processes [14]. GSK-3 $\beta$ is a serine/threonine kinase that participates in the regulation of cellular function [15]. GSK3 $\beta$ controls several extra-metabolic processes that are impaired in AKI and diabetes, including cytoskeletal dynamics, gene expression, proliferation, and apoptosis [16-18].

Oxidative stress caused by increased production of ROS leads to necrosis, apoptosis, inflammation and other disorders in AKI [19]. ROS could cause damage of renal tubular epithelial cells [20]. The redox-cycling antioxidant tempol can act as a superoxide dismutase (SOD) and a catalase member [21], thereby reducing tissue levels of both superoxide $\left(\mathrm{O}_{2}{ }^{-}\right)$ and hydrogen peroxide $\left(\mathrm{H}_{2} \mathrm{O}_{2}\right)$. It has been demonstrated to reduce the renal dysfunction caused by I/R injury, mainly through its free radical scavenging activity $[22,23]$ and improve the post-ischemic renal injury by inhibiting the neural activity of renal sympathetic nerve and ET-1 overproduction [24]. However, the detailed mechanism has not been fully elucidated. Thus, the aim of the present investigation is to study the detail protective mechanisms of tempol in renal I/R injury and its interaction with PI3K/Akt/mTOR and GSK3 $\beta$ pathways.

\section{Materials and Methods}

\section{Reagents}

Unless otherwise stated, all reagents were obtained from Sigma-Aldrich (St Louis, MO, USA).

\section{Animals}

Male C57Bl/6 mice (25-28 g, SLAC laboratory animal company, Shanghai, China) were housed under climate-controlled condition with a $12 \mathrm{~h}$ light/dark cycle and provided with standard diet and water. An acclimation period of at least 1 week was provided before initiating experimental protocols. All protocols and animal handling procedures were performed in accordance with the National Institutes of Health (NIH, USA) guidelines for the care and use of laboratory animals and were approved by the Institute Animal Care and Ethical Committee of Zhejiang University School of Medicine. 


\section{Kidney Blood Pressure Research}

Kidney Blood Press Res 2018;43:904-913

\begin{tabular}{l|l}
\hline DOI: $10.1159 / 000490338$ & (C) 2018 The Author(s). Published by S. Karger AG, Basel
\end{tabular}

Published online: 5 June, 2018

www.karger.com/kbr

Zhang et al.: Tempol Protects Against Acute Renal Injury

\section{Renal ischemia/reperfusion model}

Tempol (50 mg/kg, intraperitoneal injection) [25] was administered at 1 hour prior to the renal I/R injury. Mice were randomly divided into threegroups ( $n=8$ pergroup): sham, I/Rand tempol+I/Rgroup. Each mouse was anaesthetized with inhaled isoflurane. The right renal pedicle was clamped for 30 minutes and left nephrectomy performed to induce renal injury. After ischemia, the clamp was released for reperfusion. After the abdominal wounds being sutured, the mice were kept on a heating pad until its full consciousness. Sham group was dissected as above without clamping of the renal pedicle and left nephrectomy. The mouse temperature was monitored and maintained at $37 \pm 0.5^{\circ} \mathrm{C}$ throughout the experiment with a heating pad. Mice were decapitated at $24 \mathrm{~h}$ after reperfusion, and the kidneys were harvested for further analysis.

\section{Measurement of renal injury markers}

Blood was collected from the inferior vena cava and centrifuged at $3000 \mathrm{rpm}, 4^{\circ} \mathrm{C}$ for $15 \mathrm{~min}$. Serum creatinine and blood urea nitrogen (BUN) were tested by an automatic biochemical analyzer. The tissue concentrations of superoxide dismutase (SOD), catalase (CAT) and $\mathrm{O}_{2}^{-}$were measured by using standard assays according to manufacture instructions (SOD and CAT Assay Kit were purchased from Beyotime Biotechnology and $\mathrm{O}_{2}{ }^{-}$Assay Kit from Najing Jiancheng Bioengineering Institute, Nanjing, China).

\section{Histological study}

The kidney samples were harvested and fixed in 4\% paraformaldehyde solution $24 \mathrm{~h}$ after renal I/R injury. Fixed kidney tissues were embedded in paraffin and were sliced and stained with Periodic Acid Schiff (PAS). Ten randomly chosen fields in cortex were captured under $\times 200$ magnification. The percentage of necrotic tubules in each image was quantified as reported $[8,26,27]$. All morphometric analyses were performed in a blinded manner.

\section{Protein extraction and Western blotting}

After euthanatized, the kidneys were collected and stored at $-80^{\circ} \mathrm{C}$. Frozen kidney tissue samples were homogenized in buffer containing $50 \mathrm{mM}$ Tris-HCl, 0.5\% Triton, 4mM EGTA, 10mM EDTA, $1 \mathrm{mM} \mathrm{Na}_{3} \mathrm{VO}_{4}$, $30 \mathrm{mM}$ sodium pyrophosphate, $50 \mathrm{mM} \mathrm{NaF}, 1 \mathrm{mM}$ phenylmethylsulfonyl fluoride, $50 \mu \mathrm{g} / \mathrm{ml}$ leupeptin, 25 $\mu / \mathrm{ml}$ pepstatin A, $50 \mu \mathrm{g} / \mathrm{ml}$ trypsin inhibitor and $1 \mathrm{mmol} / \mathrm{L}$ dithiothreitol. The homogenate was centrifuged $10 \mathrm{~min}$ at $13,000 \mathrm{~g}$ at $4^{\circ} \mathrm{C}$. After determining supernatant protein concentration using Bradford's solution, samples were boiled for $3 \mathrm{~min}$ in Laemmli's sample buffer as described previously [28-30]. Samples containing equivalent amounts of protein were analyzed by $10 \%$ sodium dodecyl sulfate-polyacrylamide gel electrophoresis as described previously [31,32]. Proteins were transferred to the immobile PVDF transfer membrane for $1 \mathrm{~h}$ at $50 \mathrm{~V}$. Membranes were blocked in $20 \mathrm{mM}$ Tris- $\mathrm{HCl}, 150 \mathrm{mM} \mathrm{NaCl}$ and $0.1 \%$ Tween 20 containing $5 \%$ fat-free milk powder at room temperature for $1 \mathrm{~h}$ and immunodetected with antibodies to $\beta$-actin, p53, Bcl2, NF-кB, mTOR, p-mTOR (Abcam Cambridge), Akt, p-Akt (Ser473), GSK3 $\beta$, p-GSK3 $\beta$ (Ser9), JNK and p-JNK (Cell Signaling Technology). Membranes were incubated with the appropriate horseradish peroxidase conjugated secondary antibody (1:5000). Immunoreactivity was incubated by enhanced chemiluminescence and visualized in an automated imaging analysis system (Tanon 5200 Multi, Tanon Science \& Technology, Shanghai).

\section{Isolation and microperfusion of afferent arterioles}

The isolation and perfusion of the afferent arterioles were similar as described previously [33, 34]. Briefly, mice were anesthetized with inhaled isoflurane and kidneys were removed and sliced quickly. Kidney slice was placed in ice-cold DMEM. Glomerulus with afferent arteriole was dissected under a microscope and transferred to a temperature-regulated chamber mounted on an inverted microscope (SZX16, Olympus, Japan) with DMEM (Fig. 1). The glomerulus was held with micropipette and afferent arteriole was cannulated and perfused with a set of micropipettes. The intraluminal pressure of the perfused afferent arteriole was maintained at $60 \mathrm{mmHg}$ during experiment. 


\section{Kidney Blood Pressure Research}

Fig. 1. The renal afferent arteriolar microperfusion.
Statistical analysis

The significance between the different groups was determined using a one-way ANOVA and accepted as statistically significant at $p<0.05$. All the results were presented as mean \pm SEM.

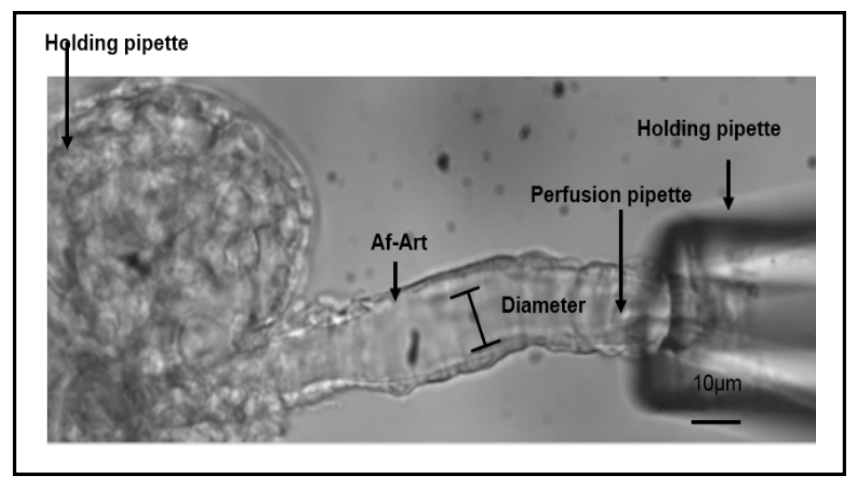

\section{Results}

Effects of tempol on renal function after $I / R$ injury

The serum creatinine and BUN increased after renal I/R injury in mice and reduced by tempol (Fig. 2).

Effect of tempol on oxidative stress related indicator levels after $I / R$ injury

SOD is an oxidoreductase that catalyzes the reaction between superoxide anions and hydrogen to yield molecular oxygen and hydrogen peroxide. Large numbers of oxygen free radicals are generated during periods of ischemia followed by reperfusion, leading to excessive SOD consumption [35]. CAT catalyzes the decomposition of hydrogen peroxide to water and oxygen [36]. They are very important enzymes in protecting the cell from oxidative damage by ROS. Surprisingly, I/R injury resulted in a significant reduction of SOD and CAT activity in kidney tissues and a significant increase of $\mathrm{O}_{2}^{-}$, while tempol prevented the decrease of SOD and CAT activity and the increase of $\mathrm{O}_{2}-$ (Fig. 3). These results suggested that tempol represses ROS accumulation by enhancing SOD and CAT activity and eliminate $\mathrm{O}_{2}^{-}$level.

\section{Effects of tempol on renal morphology after I/R injury}

PAS staining of kidney sections in I/R group exhibited wide spread necrosis of tubular epithelial cells, with a large number of tubular and necrotic cells found inside the tubular cavity. The tempol pretreatment group only showed focal tubular necrosis and edema significantly reduced. The control group showed normal renal tissue structures (Fig. 4 A, B, C and D).

Effect of tempol on the expression of PI3K/Akt/mTOR and GSK3 $\beta$ pathways after I/R injury

Renal I/R injury reduced p-Akt (Fig. $5 \mathrm{~A}$ and B), p-mTOR (Fig. $5 \mathrm{C}$ and D) and p-GSK3 $\beta$ expression (Fig. $5 \mathrm{E}$ and F). Pretreatment with tempol reversed the reduction of p-Akt, p-mTOR and $p-G S K 3 \beta$ expression.

Effect of tempol on the expression of apoptosis and inflammation related proteins after I/R injury

JNK/phosphorylated-JNK (JNK/p-JNK) regulates several important cellular functions including cell growth, differentiation, survival and apoptosis [37]. Bcl-2 is a kind of inhibitor of the cell apoptosis and could prevent the apoptosis induced by free radicals and lipid peroxidation $[38,39]$. Bcl-2 has the antioxidative characteristics in cells through participating the reduction action and inhibiting the formation of ROS [40]. The p53 is a tumor suppressor gene that plays an important role in cell cycle control and apoptosis. When tissue is exposed to I/R injury, the p53 activates the apoptotic pathway and directs cell death via apoptosis in order to protect the genome [41]. NF- $\mathrm{\kappa B}$ is a protein complex that controls transcription of 


\section{Kidney Blood Pressure Research}

Fig. 2. Effects of tempol on renal function after renal I/R injury. (A) Effects of tempol on serum creatinine after renal I/R injury. (B) Effects of tempol on serum BUN after renal I/R injury. Data are expressed as mean $\pm \mathrm{SEM}$, $(\mathrm{n}=8),{ }^{*} \mathrm{p}<0.05$ vs sham group; \# p $<0.05$ vs I/R group.

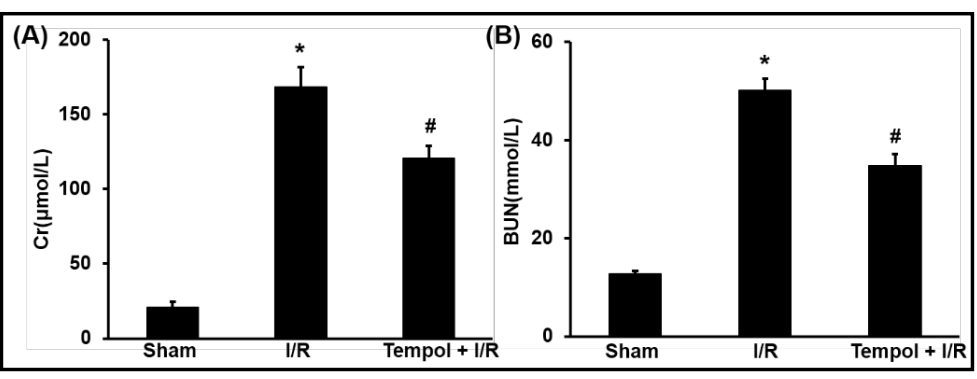

Fig. 3. Effects of tempol on oxidative stress induced by renal I/R injury. SOD, CAT and $\mathrm{O}_{2} \cdot$ in kidney were expressed as mean \pm SEM, $(\mathrm{n}=8) .{ }^{*} \mathrm{p}<0.05$ vs sham group; \# $\mathrm{p}<0.05$ vs I/R group.

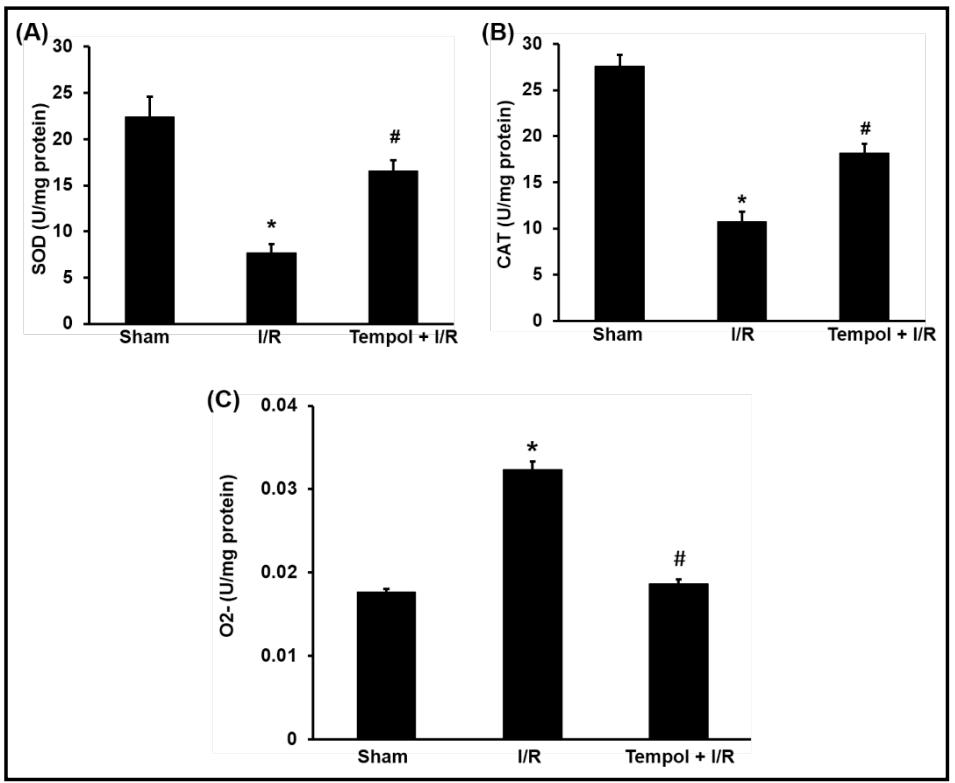

Fig. 4. Effect of tempol on the morphologic changes of kidney tissues. PAS staining kidney sections were taken from sham group (A), I/R group (B) and I/R pretreated with tempol (50 mg/kg, C) and kidney injury was quantitatively measured by percentage of tubular necrosis in the cortex (D). Data were expressed as mean \pm SEM, $n=3,{ }^{*} p<0.05$ vs sham group, $\# p<0.05$ vs I/R group.

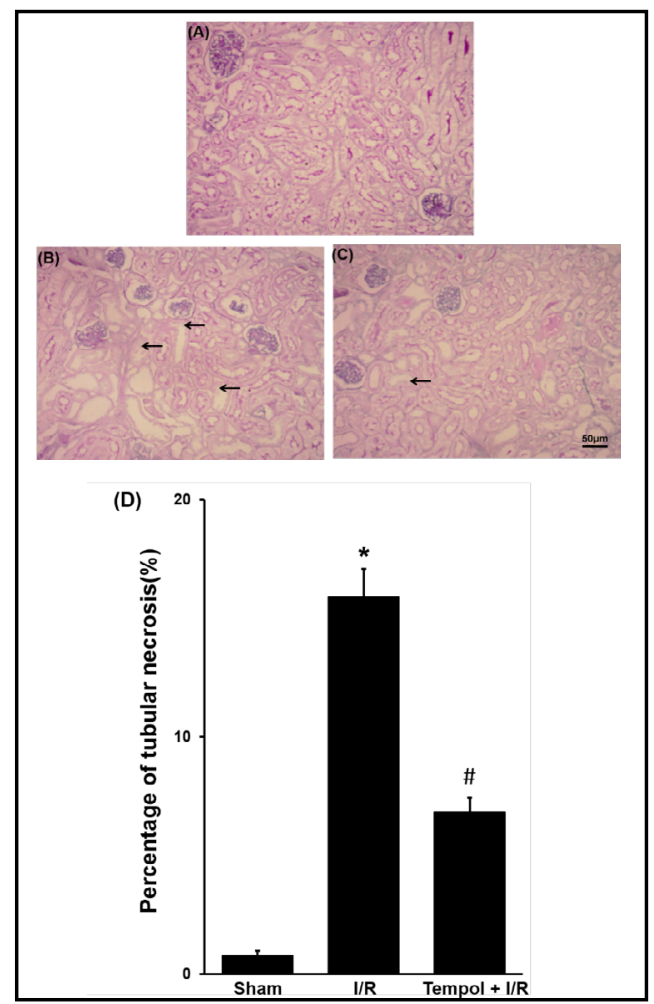




\section{Kidney Blood Pressure Research}
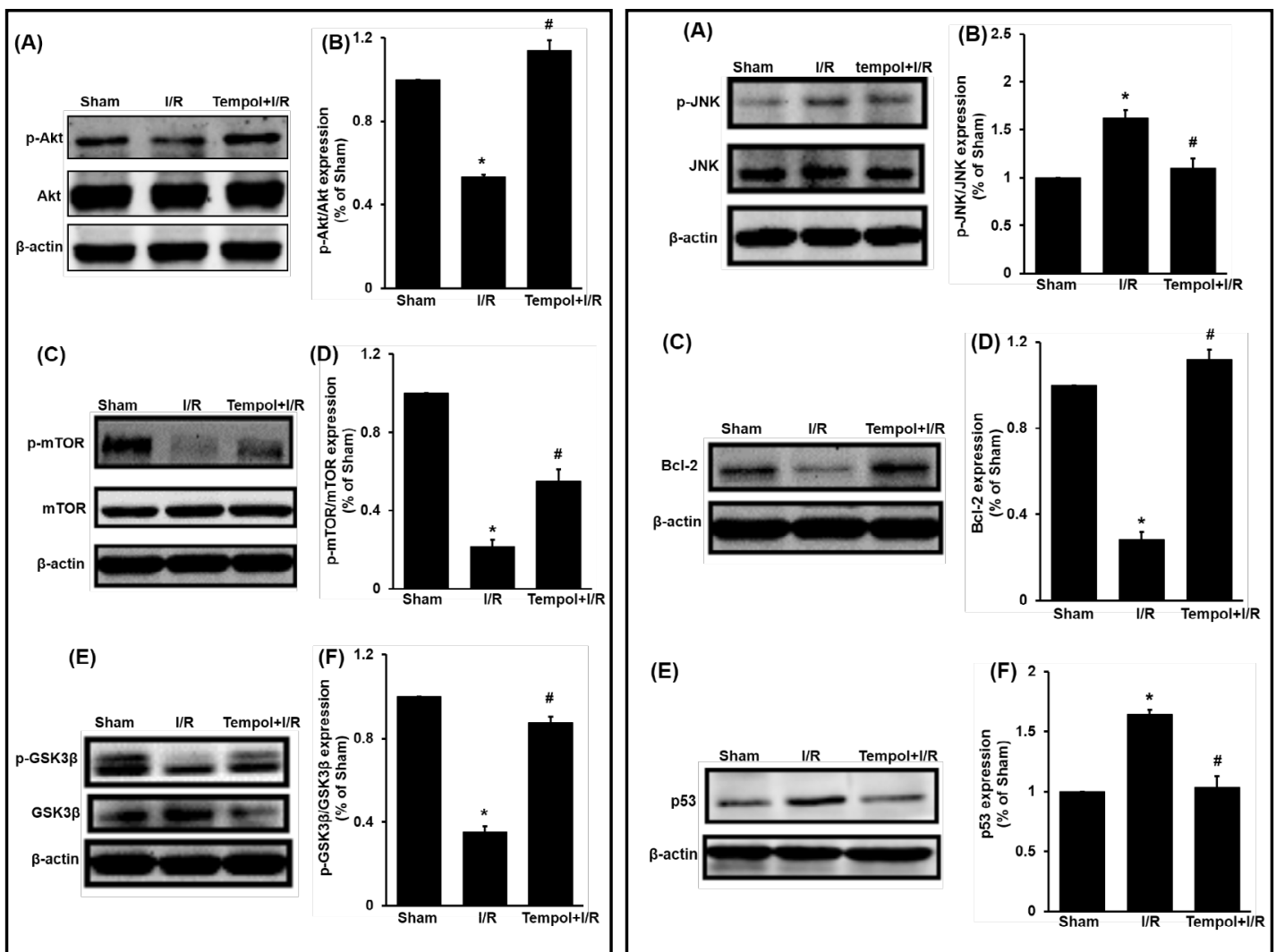

Fig. 5. Effect of tempol on the expression of Akt/ mTOR and GSK3 $\beta$ pathways in I/R injury. Data were expressed as mean $\pm \mathrm{SEM}, \mathrm{n}=5, * \mathrm{p}<0.05$ vs sham group; \# $\mathrm{p}<0.05$ vs I/R group.

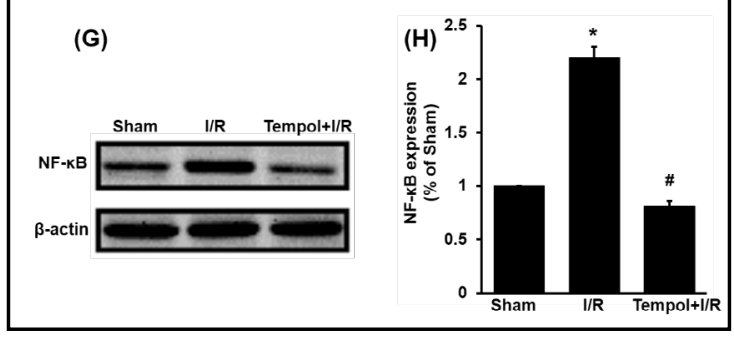

Fig. 6. Effect of tempol on the expression of apoptosis and inflammation pathways in renal I/R injury. Data were expressed as mean \pm SEM, $n=5,{ }^{*} p<0.05$ vs sham group; \# $\mathrm{p}<0.05$ vs I/R group.

DNA, cytokine production and cell survival. NF- $\kappa \mathrm{B}$ is recognized to have a potential role in apoptosis and the adaptive response to stress [42,43].

Our data showed that the expression of Bcl2 was reduced, but p-JNK, p53 and NF- $\mathrm{BB}$ were increased after renal I/R injury. These changes were reduced in mice pretreated with tempol (Fig. 6).

\section{Effect of tempol on afferent arteriolar contraction to Ang II in different groups}

After 30 min equilibration period, cumulative dose response curves of Ang II $\left(10^{-12}\right.$ to $10^{-6} \mathrm{~mol} / \mathrm{L}$ ) were obtained. Each concentration of Ang II was perfused for 2 minutes and recorded the constrictive response. In the sham group, Ang II at concentration of $10^{-9} \mathrm{~mol} / \mathrm{L}$ and above induced dose-dependent contraction of afferent arteriole. However, this was reduced significantly in the afferent arteriole after I/R injury. Pretreatment with tempol significantly reversed the reduction of afferent arteriolar contraction (Fig. 7). 


\section{Kidney Blood Pressure Research}

Fig. 7. Effect of tempol on the afferent arteriolar activity in renal I/R injury. A) The representative picture of microperfusion. Doseresponse curve for Ang II in three different groups. Arteriolar luminal diameters were given in $\mu \mathrm{m}$ (B) and contractive percent of the control diameter (C). Data were expressed as mean \pm SEM, $n=5, * p<0.05$ vs sham group; \# $\mathrm{p}<0.05$ vs I/R group.

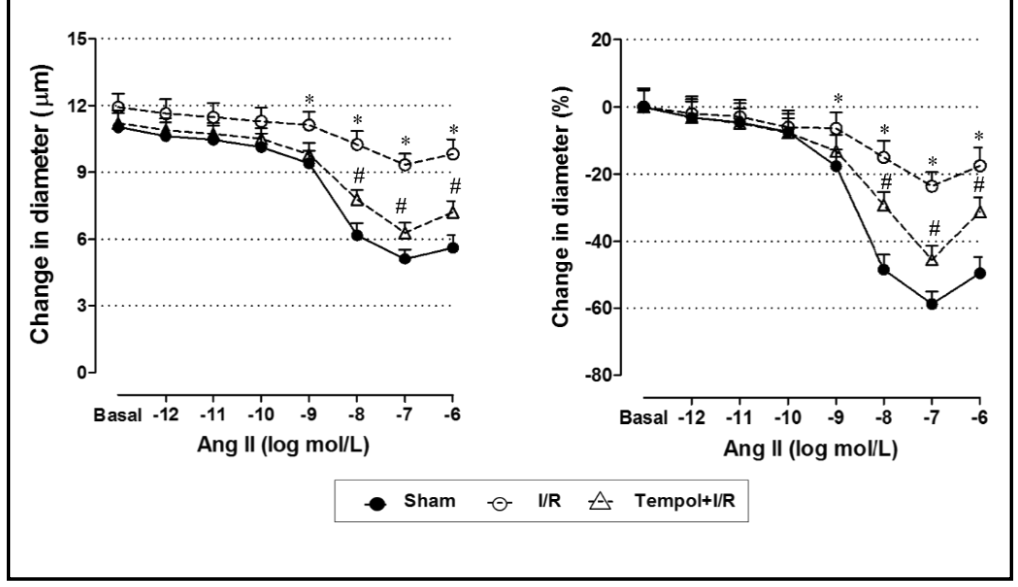

\section{Discussion}

The important findings of the present study include: (1) I/R renal injury decreased SOD and CAT enzymatic activities and tempol improved these changes. (2) tempol corrected the expression of the apoptosis and inflammation pathway related proteins of Bcl-2, p53 p-JNK/ JNK and NF- $\kappa$ B. (3) tempol restored p-mTOR, p-GSK3 $\beta$ and p-Akt activation. (4) tempol improved the afferent arteriolar contraction to Ang II.

It is well-known that NO participates in the pathophysiology of AKI and plays a great role in renal I/R injury. Imbalance between $\mathrm{O}_{2}{ }^{-}$and $\mathrm{NO}$ is an important pathogenesis of I/Rinduced AKI [44]. Tempol is reported to attenuate renal dysfunction by protecting tubular cells from oxidative stress $[22,23,25,45]$. Indeed, tempol could improve tissue $\mathrm{NO}$ and $\mathrm{PO}_{2}$, reduce inflammation and protect the kidney from I/R-induced renal injury [22, 45]. Pretreatment with tempol may reduce the renal injury by inhibiting the neural activity of renal sympathetic nerve [24]. Our results confirm the reports that tempol protects the kidney from ischemic damage, but shows a complex mechanism.

The present study demonstrated an important mechanism of cellular defense after tempol involved up-regulation of Akt and its downstream genes, including mTOR and GSK3 $\beta$. Tempol may restored Akt-dependent cytoprotective pathways by reducing the levels of ROS, lipid peroxidation [25, 46], inflammation and apoptosis [47], as well as upregulating SOD and CAT activity. Upregulating Bcl-2 expression in the tempol-treated mice after renal ischemia reduces kidney I/R injury by suppression of mitochondrial apoptosis $[48,49]$.

The microperfused afferent arteriolar technique in vitro has several advantages over other methodologies used to study the vessels in kidney. Renal afferent arterioles are the primary site of resistance in the renal circulation, their response to Ang II is very important to kidney function. Afferent arteriolar activity is a result of a number of factors. In the present study, we found that the Ang II responses were reduced in afferent arterioles in mice after I/R injury. This is in agreement with previous reports that renal microvascular reactivity reduced after the acute kidney injury $[33,50,51]$.

\section{Conclusion}

Our findings using the renal I/R injury model demonstrated that tempol effectively prevented against I/R-induced renal injury through PI3K/Akt/ mTOR and GSK3 $\beta$ signaling pathways and improved the afferent arteriolar activity in mice. 


\section{Kidney \\ Blood Pressure Research}

Zhang et al.: Tempol Protects Against Acute Renal Injury

\section{Acknowledgements}

This study was supported by research grants to En Yin Lai from the National Nature Science Foundation of China (31471100 and 31671193).

\section{Disclosure Statement}

The authors of this manuscript state that they do not have any conflict of interests and nothing to disclose.

\section{References}

1 Uchino S, Bellomo R, Goldsmith D, Bates S, Ronco C: An assessment of the RIFLE criteria for acute renal failure in hospitalized patients. Crit Care Med 2006;34:1913-1917.

2 Uchino S, Kellum JA, Bellomo R, Doig GS, Morimatsu H, Morgera S, Schetz M, Tan I, Bouman C, Macedo E, Gibney N, Tolwani A, Ronco C, Beginning, Ending Supportive Therapy for the Kidney I: Acute renal failure in critically ill patients: a multinational, multicenter study. JAMA 2005;294:813-818.

- 3 Liangos O, Wald R, O’Bell JW, Price L, Pereira BJ, Jaber BL: Epidemiology and outcomes of acute renal failure in hospitalized patients: a national survey. Clin J Am Soc Nephrol 2006;1:43-51.

4 Ali T, Khan I, Simpson W, Prescott G, Townend J, Smith W, Macleod A: Incidence and outcomes in acute kidney injury: a comprehensive population-based study. J Am Soc Nephrol 2007;18:1292-1298.

5 Murugan R, Kellum JA: Acute kidney injury: what's the prognosis? Nat Rev Nephrol 2011;7:209-217.

$\checkmark 6$ Chen J, Chen JK, Harris RC: Deletion of the epidermal growth factor receptor in renal proximal tubule epithelial cells delays recovery from acute kidney injury. Kidney Int 2012;82:45-52.

-7 Shimizu S, Saito M, Kinoshita Y, Ohmasa F, Dimitriadis F, Shomori K, Hayashi A, Satoh K: Nicorandil ameliorates ischaemia-reperfusion injury in the rat kidney. Br J Pharmacol 2011;163:272-282.

-8 Wang L, Song J, Buggs J, Wei J, Wang S, Zhang J, Zhang G, Lu Y, Yip KP, Liu R: A new mouse model of hemorrhagic shock-induced acute kidney injury. Am J Physiol Renal Physiol 2017;312:F134-F142.

9 Tong F, Zhou X: The Nrf2/HO-1 Pathway Mediates the Antagonist Effect of L-Arginine On Renal Ischemia/ Reperfusion Injury in Rats. Kidney Blood Press Res 2017;42:519-529.

10 Peng J, Ren X, Lan T, Chen Y, Shao Z, Yang C: Renoprotective effects of ursolic acid on ischemia/ reperfusioninduced acute kidney injury through oxidative stress, inflammation and the inhibition of STAT3 and NFkappaB activities. Mol Med Rep 2016;14:3397-3402.

11 Kandel ES, Hay N: The regulation and activities of the multifunctional serine/threonine kinase Akt/PKB. Exp Cell Res 1999;253:210-229.

12 Brunet A, Bonni A, Zigmond MJ, Lin MZ, Juo P, Hu LS, Anderson MJ, Arden KC, Blenis J, Greenberg ME: Akt promotes cell survival by phosphorylating and inhibiting a Forkhead transcription factor. Cell 1999;96:857-868.

13 Liu HB, Meng QH, Huang C, Wang JB, Liu XW: Nephroprotective Effects of Polydatin against Ischemia/ Reperfusion Injury: A Role for the PI3K/Akt Signal Pathway. Oxid Med Cell Longev 2015;2015:362158.

14 Liu Y: Rapamycin and chronic kidney disease: beyond the inhibition of inflammation. Kidney Int 2006;69:1925-1927.

$>15 \mathrm{Hu}$ B, Wu Y, Liu J, Shen X, Tong F, Xu G, Shen R: GSK-3beta Inhibitor Induces Expression of Nrf2/TrxR2 Signaling Pathway to Protect against Renal Ischemia/Reperfusion Injury in Diabetic Rats. Kidney Blood Press Res 2016;41:937-946.

16 Wang Z, Havasi A, Gall J, Bonegio R, Li Z, Mao H, Schwartz JH, Borkan SC: GSK3beta promotes apoptosis after renal ischemic injury. J Am Soc Nephrol 2010;21:284-294.

17 Loberg RD, Vesely E, Brosius FC 3rd: Enhanced glycogen synthase kinase-3beta activity mediates hypoxiainduced apoptosis of vascular smooth muscle cells and is prevented by glucose transport and metabolism. J Biol Chem 2002;277:41667-41673. 


\section{Kidney \\ Blood Pressure Research}

Kidney Blood Press Res 2018;43:904-913

\begin{tabular}{l|l}
\hline DOI: $10.1159 / 000490338$ & (C) 2018 The Author(s). Published by S. Karger AG, Basel
\end{tabular}

Published online: 5 June, 2018

www.karger.com/kbr

Zhang et al.: Tempol Protects Against Acute Renal Injury

18 Paeng J, Chang JH, Lee SH, Nam BY, Kang HY, Kim S, Oh HJ, Park JT, Han SH, Yoo TH, Kang SW: Enhanced glycogen synthase kinase-3beta activity mediates podocyte apoptosis under diabetic conditions. Apoptosis 2014;19:1678-1690.

19 Zhang G, Zou X, Huang Y, Wang F, Miao S, Liu G, Chen M, Zhu Y: Mesenchymal Stromal Cell-Derived Extracellular Vesicles Protect Against Acute Kidney Injury Through Anti-Oxidation by Enhancing Nrf2/ARE Activation in Rats. Kidney Blood Press Res 2016;41:119-128.

-20 Nie H, Xue X, Liu G, Guan G, Liu H, Sun L, Zhao L, Wang X, Chen Z: Nitro-oleic acid ameliorates oxygen and glucose deprivation/re-oxygenation triggered oxidative stress in renal tubular cells via activation of Nrf2 and suppression of NADPH oxidase. Free Radic Res 2016;50:1200-1213.

-21 Wilcox CS, Pearlman A: Chemistry and antihypertensive effects of tempol and other nitroxides. Pharmacol Rev 2008;60:418-469.

-22 Chatterjee PK, Cuzzocrea S, Brown PA, Zacharowski K, Stewart KN, Mota-Filipe H, Thiemermann C: Tempol, a membrane-permeable radical scavenger, reduces oxidant stress-mediated renal dysfunction and injury in the rat. Kidney Int 2000;58:658-673.

-23 Patel NS, Chatterjee PK, Chatterjee BE, Cuzzocrea S, Serraino I, Brown PA, Stewart KN, Mota-Filipe H, Thiemermann C: TEMPONE reduces renal dysfunction and injury mediated by oxidative stress of the rat kidney. Free Radic Biol Med 2002;33:1575-1589.

24 Fujii T, Takaoka M, Ohkita M, Matsumura Y: Tempol protects against ischemic acute renal failure by inhibiting renal noradrenaline overflow and endothelin-1 overproduction. Biol Pharm Bull 2005;28:641645.

25 Zhang G, Wang Q Zhou Q, Wang R, Xu M, Wang H, Wang L, Wilcox CS, Liu R, Lai EY: Protective Effect of Tempol on Acute Kidney Injury Through PI3K/Akt/Nrf2 Signaling Pathway. Kidney Blood Press Res 2016;41:129-138.

-26 Wei J, Song J, Jiang S, Zhang G, Wheeler D, Zhang J, Wang S, Lai EY, Wang L, Buggs J, Liu R: Role of intratubular pressure during the ischemic phase in acute kidney injury. Am J Physiol Renal Physiol 2017;312:F1158-F1165.

27 Melnikov VY, Faubel S, Siegmund B, Lucia MS, Ljubanovic D, Edelstein CL: Neutrophil-independent mechanisms of caspase-1- and IL-18-mediated ischemic acute tubular necrosis in mice. J Clin Invest 2002;110:1083-1091.

28 Liao MH, Xiang YC, Huang JY, Tao RR, Tian Y, Ye WF, Zhang GS, Lu YM, Ahmed MM, Liu ZR, Fukunaga K, Han F: The disturbance of hippocampal CaMKII/PKA/PKC phosphorylation in early experimental diabetes mellitus. CNS Neurosci Ther 2013;19:329-336.

29 Han F, Chen YX, Lu YM, Huang JY, Zhang GS, Tao RR, Ji YL, Liao MH, Fukunaga K, Qin ZH: Regulation of the ischemia-induced autophagy-lysosome processes by nitrosative stress in endothelial cells. J Pineal Res 2011;51:124-135.

-30 Zhang GS, Ye WF, Tao RR, Lu YM, Shen GF, Fukunaga K, Huang JY, Ji YL, Han F: Expression profiling of $\mathrm{Ca}(2+)$ /calmodulin-dependent signaling molecules in the rat dorsal and ventral hippocampus after acute lead exposure. Exp Toxicol Pathol 2012;64:619-624.

-31 Zhang GS, Tian Y, Huang JY, Tao RR, Liao MH, Lu YM, Ye WF, Wang R, Fukunaga K, Lou YJ, Han F: The gamma-secretase blocker DAPT reduces the permeability of the blood-brain barrier by decreasing the ubiquitination and degradation of occludin during permanent brain ischemia. CNS Neurosci Ther 2013;19:53-60.

-32 Han F, Tao RR, Zhang GS, Lu YM, Liu LL, Chen YX, Lou YJ, Fukunaga K, Hong ZH: Melatonin ameliorates ischemic-like injury-evoked nitrosative stress: Involvement of HtrA2/PED pathways in endothelial cells. J Pineal Res 2011;50:281-291.

-33 Huang Q Wang Q Zhang S, Jiang S, Zhao L, Yu L, Hultstrom M, Patzak A, Li L, Wilcox CS, Lai EY: Increased hydrogen peroxide impairs angiotensin II contractions of afferent arterioles in mice after renal ischaemiareperfusion injury. Acta Physiol (Oxf) 2016;218:136-145.

34 Lai EY, Martinka P, Fahling M, Mrowka R, Steege A, Gericke A, Sendeski M, Persson PB, Persson AE, Patzak A: Adenosine restores angiotensin II-induced contractions by receptor-independent enhancement of calcium sensitivity in renal arterioles. Circ Res 2006;99:1117-1124.

-35 Roth E, Hejjel L, Jaberansari M, Jancso G: The role of free radicals in endogenous adaptation and intracellular signals. Exp Clin Cardiol 2004;9:13-16. 


\section{Kidney \\ Blood Pressure Research}

Kidney Blood Press Res 2018;43:904-913

\begin{tabular}{l|l}
\hline DOI: $10.1159 / 000490338$ & (C) 2018 The Author(s). Published by S. Karger AG, Basel
\end{tabular}

Published online: 5 June, 2018

www.karger.com $/ \mathrm{kbr}$

-36 Chelikani P, Fita I, Loewen PC: Diversity of structures and properties among catalases. Cell Mol Life Sci 2004;61:192-208.

-37 Iyer AK, Rojanasakul Y, Azad N: Nitrosothiol signaling and protein nitrosation in cell death. Nitric Oxide 2014;42:9-18.

-38 Wang CB, Yao RY, Liu ZT, Zhong WZ, Liu XP, Wang YJ: Protective effect of polypeptide from Chlamys farreri on hairless mice damaged by ultraviolet A. Acta Pharmacol Sin 2002;23:813-818.

-39 Hockenbery D, Nunez G, Milliman C, Schreiber RD, Korsmeyer SJ: Bcl-2 is an inner mitochondrial membrane protein that blocks programmed cell death. Nature 1990;348:334-336.

-40 Chen CC, Liu ZM, Wang HH, He W, Wang Y, Wu WD: Effects of ulinastatin on renal ischemia-reperfusion injury in rats. Acta Pharmacol Sin 2004;25:1334-1340.

-41 Balint EE, Vousden KH: Activation and activities of the p53 tumour suppressor protein. Br J Cancer 2001;85:1813-1823.

42 Ningegowda R, Shivananju NS, Rajendran P, Basappa, Rangappa KS, Chinnathambi A, Li F, Achar RR, Shanmugam MK, Bist P, Alharbi SA, Lim LH, Sethi G, Priya BS: A novel 4, 6-disubstituted-1, 2,4-triazolo-1, 3,4-thiadiazole derivative inhibits tumor cell invasion and potentiates the apoptotic effect of TNFalpha by abrogating NF-kappaB activation cascade. Apoptosis 2016;10.1007/s10495-016-1312-8

-43 Li Z, Nickkholgh A, Yi X, Bruns H, Gross ML, Hoffmann K, Mohr E, Zorn M, Buchler MW, Schemmer P: Melatonin protects kidney grafts from ischemia/reperfusion injury through inhibition of NF-kB and apoptosis after experimental kidney transplantation. J Pineal Res 2009;46:365-372.

44 Zhu YB, Zhang YP, Zhang J, Zhang YB: Evaluation of Vitamin C Supplementation on Kidney Function and Vascular Reactivity Following Renal Ischemic Injury in Mice. Kidney Blood Press Res 2016;41:460-470.

$>45$ Wilcox CS: Effects of tempol and redox-cycling nitroxides in models of oxidative stress. Pharmacol Ther 2010;126:119-145.

-46 Aksu U, Ergin B, Bezemer R, Kandil A, Milstein DM, Demirci-Tansel C, Ince C: Scavenging reactive oxygen species using tempol in the acute phase of renal ischemia/reperfusion and its effects on kidney oxygenation and nitric oxide levels. Intensive Care Med Exp 2015;3:57.

47 Ahmed LA, Shehata NI, Abdelkader NF, Khattab MM: Tempol, a superoxide dismutase mimetic agent, ameliorates cisplatin-induced nephrotoxicity through alleviation of mitochondrial dysfunction in mice. PLoS One 2014;9:e108889.

48 Chien CT, Chang TC, Tsai CY, Shyue SK, Lai MK: Adenovirus-mediated bcl-2 gene transfer inhibits renal ischemia/reperfusion induced tubular oxidative stress and apoptosis. Am J Transplant 2005;5:1194-1203.

49 Suzuki C, Isaka Y, Shimizu S, Tsujimoto Y, Takabatake Y, Ito T, Takahara S, Imai E: Bcl-2 protects tubular epithelial cells from ischemia reperfusion injury by inhibiting apoptosis. Cell Transplant 2008;17:223-229.

50 Wilkes BM, Caldicott WJ, Schulman G, Hollenberg NK: Loss of the glomerular contractile response to angiotensin in rats following myohemoglobinuric acute renal failure. Circ Res 1981;49:1190-1195.

-51 Guan Z, Gobe G, Willgoss D, Endre ZH: Renal endothelial dysfunction and impaired autoregulation after ischemia-reperfusion injury result from excess nitric oxide. Am J Physiol Renal Physiol 2006;291:F619628. 